\title{
Is Dumping Still Harmful? New Thinking on Antidumping in the Global Free Trade
}

\section{Ying $\mathrm{Bi}^{*}$}

The debate on whether antidumping law should be integrated into competition law is a relatively new but very significant one. Building on prior scholarship, this paper attempts to contribute to the debate by reexamining the fundamental justification of antidumping law. An exploration into the economic theories of dumping and the evolution of antidumping law indicates that the current antidumping system neither serves the broad goal of preventing 'unfair trade' nor functions as a 'quasi-safeguard' mechanism. The only rationale for antidumping law is that it deals with international predatory dumping. Modern competition rules target the same predatory conduct but they are more meticulous than antidumping law and are less susceptible to protectionist abuse. In light of this, the paper advocates the substitution of antidumping law by competition law. To achieve this, the paper suggests a gradual approach. Substitution could first be achieved in bilateral and regional trade areas before being implemented at the level of WTO.

\section{Keywords}

Antidumping, Predatory Dumping, Competition, Fair Trade, Interface Theory, Predatory Pricing

Neither the GATT nor the WTO Agreements on the subject set forth any clear explanation of why the practice of 'dumping' is considered 'unfair' so as to

* Assistant professor of law at Zhejiang University in Hangzhou, China. LL.B./LL.M.(Tsinghua), LL.D.(Kyushu). This paper presents one of the stage achievements of the National Social Science Fund Project of China (No.11CFX080) titled, "The Harmonization of Antidumping Rules and Competition Rules in the China-Japan-Korea FTAs." The author gratefully acknowledges the insightful comments by two anonymous reviewers of the Journal. Special thanks also go to Simon Vande Walle for his editorial suggestions. The author can be contacted at: biying@zju.edu.cn / Address: Zhejiang University Guanghua Law School, 51 Zhijiang Road, Hangzhou, Zhejiang, P.R.China. 
warrant remedial measures. Rather the 'unfairness' of the practice appears to have seemed self-evident to legislators and trade negotiators. ${ }^{1}$

\section{Introduction}

With the proliferation of antidumping laws and actions around the world, the antidumping rules' increasing potential for protectionist abuse has been criticized in almost all of the current literature. ${ }^{2}$ Thousands of pages with various proposals have been written, all of which contain the same purpose of reforming the antidumping system. Most scholars are of the opinion that the misuse of antidumping is mainly due to its arbitrary and biased rules and procedures, so continuous efforts must be made to make them more stringent and transparent, less arbitrary and abusive. ${ }^{3}$ However, years of efforts at WTO devoted to the Antidumping Agreement ("ADA") seem to suggest that there are no substantial improvements; many of the practices that have been identified as leading to significant protectionist biases remain untouched. ${ }^{4}$ Recently, an increasing number of scholars have started to question the fundamental basis for the existence of the entire antidumping system. They have pointed out that antidumping rules are established based on several false premises without justification from the perspective of competition. In fact, those rules are anti-competitive in many respects. Hence, they argue that further fine-tuning and refining of antidumping policy is not the answer to prevent its misuse. Rather, the antidote to the abuses is competition policy. Efforts should be directed at integrating antidumping with competition. This has become known as the 'substitution debate.

1 P. Ehrenhaft, Is Interface of Antidumping and Antitrust Laws Possible? 34 Geo. Wash. InT’L L. Rev. 367 (2002).

2 B.Lindsey \& D. Ikenson, Antidumping Exposed : the Devilish Details of Unfair Trade Law viii (2003).

3 A. Aggrawal, The WTO Antidumping Code: Issues for Review in Post-Doha Negotiations, 99 Working Paper (2003), available at http://www.icrier.org/pdf/WP99.pdf (last visited on Apr. 5, 2013)

4 B. Hoekman \& P. Mavroidis, Antitrust-Based Remedies and Dumping in International Trade, 1347 Policy Research Working Paper (1994), available at http://www-wds.worldbank.org/servlet/WDSContentServer/WDSP/IB/1994/08/ 01/000009265_3970716141633/Rendered/PDF/multi0page.pdf (last visited on Apr. 5, 2013).

5 S. Waller, Bringing Globalism Home: Lessons from Antitrust and Beyond, 32 LoY. U. CHI. L. J. 113 (2000). See also M.Taylor, International Competition Law: A New Dimension for the WTO? 260-285 (2006); A. Knorr, Antidumping Rules vs. Competition Rules, Institution for World Economics and International Management (2004), available at http://www.iwim.uni-bremen.de/publikationen/pdf/W031.pdf (last visited on Apr. 5, 2013); J. Finger \& A. Zlate, Antidumping: Prospects for Discipline from Doha Negotiations, Working Papers in Economics (2005),

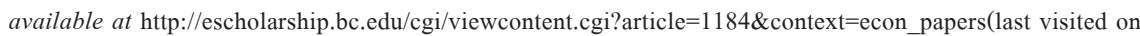
Apr. 5, 2013) ; I. Wooton \& M. Zanardi, Trade and Competition Policy: Anti-Dumping versus Anti-Trust (2002), available at http://homepages.strath.ac.uk/ hbs03116/Research/Trade\%20and\%20Competition\%20Policy\%20 Final.pdf(last visited on Apr. 5, 2013); G. Niels, What is Antidumping Policy Really About? 14 J. Econ. SuRv. 485 
Meanwhile, a more ambitious proposal is to direct efforts toward the substitution of most of the trade policy instruments, including antidumping, countervailing duties and safeguards, by a broader application of competition policies and extraterritorial jurisdiction. ${ }^{6}$ This paper narrows the discussion by focusing on the relationship between antidumping and competition rules.

The use and abuse of antidumping actions has continued unabated, especially by the US and the EU. There is also increased use of antidumping duties by developing countries including India, Brazil, South Africa, even China, as a tit-for-tat strategy. As the protectionist abuse of antidumping has become more severe, there is a need to explore antidumping law's fundamental justification. Most of the time, the idea that "dumping is harmful" is taken for granted and does not have to be proven in antidumping investigations. Perhaps dumping is perceived to be harmful, but the public has no thorough understanding of dumping and thus fails to appreciate how often it results from ordinary economic forces and how often one's own nationals engage in it. Hence, the logical remedy would inform the public of the true nature of dumping. ${ }^{8}$

This research will carefully examine the fundamental justification of antidumping law and its possible substitution by competition law, in particular, its rules on 'predatory pricing.' This paper is composed of five parts including short Introduction and Conclusion. Part two will briefly describe the debate on antidumping and competition in WTO, so as to identify three of the main different viewpoints on the justification of antidumping law. Part three will explore the economic theories of dumping as well as the evolution of antidumping law. Part four will argue that dumping should be addressed by predatory pricing rules rather than antidumping rules. Acknowledging that legal, institutional and political difficulties have been among the main obstacles so far to actually replacing antidumping rules with competition rules, the author will conclude with a proposal to gradually achieve substitution by first implementing it in bilateral or regional

(2002); C. Barfield, Antidumping: Time to: (1) Go Back to Basics; And (2) Politicize the Final Outcome; Or (3) Substitute Safeguards for Antidumping Actions, Paper prepared for the Centennial of Anti-Dumping Legislation and Implementation Symposium (2004), available at http://fordschool.umich.edu/rsie/Conferences/ADSym/Barfield. pdf(last visited on Apr. 5, 2013).

6 J. Guasch \& S. Rajapatirana, Antidumping and Competition Policies in Latin America and Caribbean: Total Strangers or Soul Mates? 1958 World Bank Working Paper (1998), available at http://www-wds.worldbank.org/external/default/ WDSContentServer/IW3P/IB/1998/08/01/000009265_3980929145955/additional/108508322_20041117171517.pdf (last visited on Apr. 5 , 2013).

7 Junji Nakagawa ed., Anti-Dumping Laws and Practices of The New Users 12 (2007).

8 A. Sykes, Antidumping and Antitrust: What Problems Does Each Address? in Brookings Trade Forum 38 (R. Lawerence ed., 1998). 
trade areas, before taking it to the level of WTO.

\section{The Debate on Competition and Antidumping in WTO}

The relationship between competition and trade has generated heated discussion within WTO. ${ }^{9}$ A survey of all the documents of the WTO's Working Group on the Interaction between Trade and Competition Policy ("WGTCP") from 1997 to 2004 suggests that one of the key points of contention among governments is the justification for antidumping law. ${ }^{10}$ This issue determines the link with competition law. The governments' opinions can be categorized into the following three main kinds.

\section{A. Predatory Pricing and Monopolizing Dumping}

The first viewpoint is that antidumping law has or should have the same justification as competition law. Hence, the appropriate way to cope with its anti-competitive effects is to bring it in line with competition policy or substitute it entirely with competition law. ${ }^{11}$ Countries such as Japan, Korea, Peru, Mexico, Chile, and Hong Kong have advocated this solution. Japan, e.g, asserted that both antidumping law and competition law have the identical objective of tackling predatory pricing in different areas; the former addresses such pricing in international trade, whereas the latter seeks to eliminate predatory pricing in domestic trade. ${ }^{12}$ Since there is significant doubt about the economic validity of the criteria for imposing antidumping measures, a possible reform would be to improve the criteria by introducing the perspective of competition policy. ${ }^{13}$ Korea shared the same opinion. By exploring whether antidumping rules are justifiable from an

9 M. Calliari, Antitrust and Trade, 8 COMPETITION L. INT'L 59 (2012).

10 See The WGTCP website, available at http://www.wto.org/english/tratop_e/comp_e/comp_e.htm(last visited on Apr. 5, 2013).

11 Waller, supra note 5. See also P. Lloyd, Anti-dumping and Competition Law, in 2 The World Trade Organization: Legal, Economic and Political Analysis 80 (P. Macrory et al. ed., 2005).

12 See Communication from Japan (WT/WGTCP/W/92, Sept. 1998), available at https:/docs.wto.org/dol2fe/Pages/ FE_Search/FE_S_S009-1.aspx?language=E\&CatalogueIdList $=42923,22122,27089,16325,12157,32887,27071,3501$ 2,22090,28500\&CurrentCatalogueIdIndex=7\&FullTextSearch= (last visited on Apr. 5, 2013).

13 Id. 
economic perspective, Korea considered that unless predatory intent is confirmed, antidumping regulations do not make any economic sense but merely result in anti-competitive and protective effects. ${ }^{14}$ Accordingly, antidumping law is not the optimal response to dumping. Instead, the best policy is to remove the main cause of dumping, i.e. to break down the monopoly status of firms in the exporting countries. ${ }^{15}$ Hong Kong also argued that the justification of antidumping law is similar to that of competition law. It suggested that "the objective of antidumping law be limited to punishing 'monopolizing dumping." 16

\section{B. Maintaining the Multilateral Trading System and a Level Playing Field}

The US is the strongest supporter of the viewpoint that antidumping law and antitrust law have totally different objectives and seek to remedy different problems. ${ }^{17}$ It claimed that antidumping law is a trade remedy that the WTO members have agreed upon as necessary to the "maintenance of the multilateral trading system." ${ }^{18}$ According to the US, a review of antidumping laws and their history prior to GATT showed that the true motive for the early antidumping laws is a general, but undefined, concern for 'fairness' rather than one that foreign "trusts or combines" might monopolize the domestic market. ${ }^{19}$ To achieve this 'maintenance' function, antidumping rules allow countries to offset the injurious dumping and thereby represent an effort to promote 'fair trade.' Antidumping law specifically maintains a "level playing field" among producers in different countries by coping with two issues. One is to protect against adverse trade effects that can arise from "market-distortive government industrial policies" and the other is to neutralize inequities that may arise from differences in national economic systems, i.e. "the

14 See Communication from the Republic of Korea (WT/WGTCP/W/90, Sept. 1998), available at https://docs.wto.org/ dol2fe/Pages/FE_Search/FE_S_S009-1.aspx?language=E\&CatalogueIdList $=11067,53177,7746,21601,12132,16958$, $5565,10912,15610,11874 \&$ CurrentCatalogueIdIndex=1\&FullTextSearch= (last visited on Apr. 5, 2013).

15 Id.

16 See Communication from Hong Kong, China (WT/WGTCP/W/85, Aug. 1998), available at https://docs.wto.org/ dol2fe/Pages/FE_Search/FE_S_S009-1.aspx?language=E\&CatalogueIdList=11067,53177,7746,21601,12132,16958, $5565,10912,15610,11874 \&$ CurrentCatalogueIdIndex=5\&FullTextSearch= (last visited on Apr. 5, 2013).

17 See Communication from the United States (WT/WGTCP/W/88, Aug. 1998), available at https://docs.wto.org/ dol2fe/Pages/FE_Search/FE_S_S009-1.aspx?language=E\&CatalogueIdList=11067,53177,7746,21601,12132,16958, 5565,10912,15610,11874\&CurrentCatalogueIdIndex=4\&FullTextSearch= (last visited on Apr. 5, 2013).

18 Id. For details, see Z. Maurizio, Antidumping: A Problem in International Trade (2005), available at http://papers. ssrn.com/sol3/papers.cfm?abstract_id=800406\#PaperDownload (last visited Apr. 5, 2013).

19 Supra note 17. 
interaction of different economic systems. ${ }^{20}$

In its communication to WTO, the US discussed the specific situations of "marketdistortive government industrial polices" and "differences in national economic systems" at length. ${ }^{21}$ In terms of the former, the US argues that although these policies take on many different forms, they provide similar artificial advantages to the benefiting producers. ${ }^{22}$ Market-distortive government industrial policies can be categorized in four groups as follows:

1. Government industrial policies which combine limits on domestic competition with market access barriers that keep out foreign competitors;

2. Domestic price controls, which governments can use in a number of ways to support domestic industries;

3. Government subsidization, particularly where market forces do not drive the subsidy recipients to pass on the subsidy benefits to consumers in order to remain competitive in their home market; and

4. State trading arrangements, typically involving commodity products such as agricultural products. ${ }^{23}$

Regarding the latter - the interaction of different economic systems - the US considered that in many circumstances the differences between two national economic systems result not only from the prevailing business climate or culture, but can also be attributed to the role which the government chooses to play in how business is conducted. ${ }^{24}$ The following five examples were offered:

1. When social and legal arrangements for employment and under-employment differ between countries, with labor being more of a fixed cost in one country and more of a variable cost in another country;

2. Where the business climates in the exporting and importing countries give rise to differing debt-equity structures and debt burdens;

3. Where government-tolerated relationships among businesses fundamentally vary between the exporting and importing countries;

4. Where the government has a standing practice of adopting market-stabilization measures and tolerating collusive behavior among domestic producers once

20 Id.

21 Id. See also A. Wolff, Trade and Antitrust: Is Rapprochement Desirable? Is It Possible? The (Notionally) Bridgeable Chasm between Antitrust and Trade Policy, 47 N.Y.L. Sch. L. Rev. 167-190 (2003).

22 Supra note 17.

23 Id.

24 Id. 
a product market becomes mature, with the result that market shares among domestic producers become stagnant and price competition is eliminated; and

5. Where economies make use of State planning. In these economies, unlike in market economies, the government will issue directives to producers to achieve a certain level of exports. ${ }^{25}$

The EU also states that modern competition law and antidumping law apply in different economic, legal and institutional contexts: the former applies in principle within the context of an integrated market, whereas the latter applies in an economic setting which is still characterized by border measures and other regulatory obstacles and distortions of trade. ${ }^{26}$ Without referring to the earliest history of antidumping law, the EU argued that the WTO ADA is aimed at removing the "trade-distorting effects" of dumped imports and to restore effective competition in the market when injury is being caused to a domestic industry. ${ }^{27}$ In most situations, the "trade-distorting effects" refer to market segmentation and closed home markets in so-called non-market economic countries. ${ }^{28}$ Notwithstanding, the EU differed from the US in that it showed a much greater interest in the unification of global competition law. In the Report of the Group of Experts to the European Commission, it was claimed that the abuse of antidumping law could be prevented by creating a global competition law. ${ }^{29}$ To the extent that countries enforce their competition laws more strictly and further progress is made in the integration of markets, it can be expected that the need to have recourse to antidumping action would be reduced over time. ${ }^{30}$

25 Id.

26 See Communication from the European Community and Its Member States (WT/WGTCP/W/78, Jul. 1998), available at $\mathrm{https}$ //docs.wto.org/dol2fe/Pages/FE_Search/FE_S_S009-1.aspx ?language=E\&CatalogueIdLi st $=33021,32534,21133,21131,29425,52270,38270,36793,43244,22130,42923,22122,27089,16325,12157,32887$, $27071,35012,22090,28500,11067,53177,7746,21601,12132,16958,5565,10912,15610,11874,15611,13586,11804$, $16748,61172,13229,22905,29451,11994,22897,29434,28165,11323,7728,27391,25298,45463,23306,5927,17940 \&$ CurrentCatalogueIdIndex $=32 \&$ FullTextSearch $=$ (last visited on Apr. 5, 2013).

27 Id.

28 For details, see E. Vermulst, Competition and Anti-dumping: Continued Peaceful Co-existence? 21 (1999), available at $\mathrm{http}: / /$ papers.ssrn.com/sol3/papers.cfm?abstract_id=200616 (last visited on Apr. 5 , 2013).

29 European Commission, Competition Policy in the New Trade Order: Strengthening International Cooperation and Rules (1995), available at http://aei.pitt.edu/4112/1/4112.pdf; http://aei.pitt.edu/35503/1/A243.pdf (last visited on Apr. 5, 2013).

30 Supra note 26. 


\section{From 'Predatory Pricing' to "Protection from Foreign Competition"}

The third viewpoint considers that although antidumping law and competition law may have different objectives, antidumping law should be reformed by competition policy and substituted by competition law because it results in many anti-competitive effects. ${ }^{31}$ This view is held by quite a few countries, such as Australia, New Zealand and Australia. It did not state clearly what the respective justifications of antidumping law and competition law are. Instead, it pointed out that Australia's experience has highlighted that antidumping and competition matters could intersect. ${ }^{32}$ Moreover, conceptually, antidumping matters could be of concern to competition authorities and are an important complement to policies dealing with price discrimination in the domestic sector. ${ }^{33}$ New Zealand recognized that the earliest antidumping laws were founded on the need to deal with international price predation, but this focus has long since been lost. At present, antidumping law is viewed as one of the trade policies that protect domestic industries from foreign competition. Thus, competition policy tends to view antidumping laws as limiting competition by providing a margin of protection for uncompetitive domestic producers. ${ }^{34}$

\section{Summary}

The exploration into the justifications of antidumping law suggests that three main justifications have been put forward. The first one applies an efficiency analysis; it considers that the objective of antidumping law should be to protect against anti-competitive dumping such as predatory or monopolizing dumping. Japan and Korea hold this view; they argue for substituting antidumping law by competition

31 Lloyd, supra note 11, at 75. See also R. Lipstein, Using Antitrust Principles to Reform Antidumping Law, in GLOBAL Competition Pol'y 436 (E. Graham et al. eds., 1997); J. Araujo, Legal and Economic Interfaces between Antidumping and Competition Policy, CEPAL-SERIE Comercio Internacional (2001), available at http:/www.eclac.cl/publicaciones/ xml/0/9040/1cl1685i.pdf (last visited on Apr. 5, 2013).

32 See Communication from Australia (WT/WGTCP/W/98, Sept. 1998), available at https://ocs.wto.org/dol2fe/Pages/ FE_Search/FE_S_S009-1.aspx?language $=$ E\&CatalogueIdList $=33021,32534,21133,21131,29425,52270,38270,36793$, $43244,22130,42923,22122,27089,16325,12157,32887,27071,35012,22090,28500,11067,53177,7746,21601,12132$, $16958,5565,10912,15610,11874,15611,13586,11804,16748,61172,13229,22905,29451,11994,22897,29434,28165$, $11323,7728,27391,25298,45463,23306,5927,17940 \&$ CurrentCatalogueIdIndex=18\&FullTextSearch= (last visited on Apr. 5, 2013).

$33 I d$.

34 See Communication from New Zealand (WT/WGTCP/W/81, Aug. 1998), available at https://docs.wto.org/dol2fe/ Pages/FE_Search/FE_S_S009-1.aspx?language=E\&CatalogueIdList=33021,32534,21133,21131,29425,52270,38270, $36793,43244,22130,42923,22122,27089,16325,12157,32887,27071,35012,22090,28500,11067,53177,7746,21601$, $12132,16958,5565,10912,15610,11874,15611,13586,11804,16748,61172,13229,22905,29451,11994,22897,29434$, $28165,11323,7728,27391,25298,45463,23306,5927,17940 \&$ CurrentCatalogueIdIndex=27\&FullTextSearch $=($ last visited on Apr. 5, 2013). 
law. The second one alleges that antidumping law is purported to protect domestic industries against 'unfair' foreign trade resulting from either market-distortive government industrial policies or different economic structures. The WTO members such as the US and the EU hold this opinion. In particular, the US is strongly against substitution. The third one is the viewpoint that antidumping law is used to protect domestic industries from foreign competition, or, in other words, serves as a quasisafeguard measure. Countries holding this view include Australia and New Zealand.

The US has argued that part of antidumping law's responsibility is to protect domestic industries from different economic structures. This means that antidumping should be a quasi-safeguard measure. This argument can be supported by the interface theory, which favors the application of antidumping law as a buffer, or a "meditative or interface mechanism" between social, economic, and structural differences present in international trade. ${ }^{35}$ Since the distinction between fair and unfair trade has become increasingly blurred, what seems 'unfair' to members of one society may seem perfectly fair to those of another society. Antidumping rules should be viewed as a one of the 'safeguards' rather than as a tool to prevent 'unfair trade. ${ }^{36}$ In his book, Jackson wrote that:

As world economic interdependence has increased, it has become more difficult to manage relationships among various economies. This problem is analogous to the difficulties involved in trying to get two computers of different designs to work together. To do so, one needs an 'interface' mechanism to mediate between the two computers. Likewise in international economic relations, particularly in trade, some 'interface mechanism' may be necessary to allow different economic systems to trade together harmoniously. ${ }^{37}$

Denton also deemed that:

This [antidumping law] function would not attempt to cleanse the international system of distortions, but only to subdue protectionist pressure by reducing the 'unfairness' of foreign commercial structures. In this light, the international sanctioning of national rules is a 'buffer' which ameliorates the effects of structural differences ... the interface argument also suggests that maybe national

35 G. Marceau, Anti-dumping and Anti-trust Issues in Free-trade Areas 46 (1994).

36 J. Jackson, The World Trading System: Law and Policy of International, Economic Relations 247-248 (2nd ed. 1997).

37 Id. at 248. 
antidumping laws operate [as] a de facto safeguard measure. ${ }^{38}$

To sum up, three main different viewpoints on the justification of antidumping law can be identified as follows:

1. Eliminate 'predatory dumping' intended to monopolization;

2. Protect against 'unfair trade' resulted from various market-distortive government industrial policies; and

3. Function as a 'quasi safeguard' measure to mitigate the effects of different economic structures.

\section{Seeking the Truth: Why Is Dumping Harmful?}

\section{A. Predatory Dumping: The Only Justification of Antidumping Law}

\section{Dumping in Economics}

In line with the development of antidumping rules, various economic theories on dumping have emerged. ${ }^{39}$ The traditional dumping theory by Viner and the modern dumping theory by Willig are of great influence. Viner was the first to present a comprehensive theoretical treatise on dumping. ${ }^{40}$ His dumping theory, which classified dumping in light of both the motives of dumper and the continuity of dumping, had an essential influence on the subsequent literature. ${ }^{41}$ According to Viner, dumping is defined as "price-discrimination between national markets." 42 In the evaluation of the effects of dumping, an efficiency analysis that explores whether consumer welfare weighs more than industry interest is applied to each type: sporadic dumping, short-run or intermittent dumping, as well as long-run or continuous dumping. ${ }^{43}$ Viner concludes that dumping can be regarded as harmful in short-run dumping only under two circumstances. One is the threat of predatory dumping, likely to facilitate the acquisition of monopoly control by establishing

38 R. Denton, (Why) Should Nations Utilize Antidumping Measures?, 11 Mrch. J. INT'L L. 250 (1989). See also supra note 35 , at 47 .

39 Niels, supra note 5, at 467-492.

40 Id. at 471.

41 Id. at $472-473$.

42 J. Viner, Dumping: A Problem in International Trade 3 (1st ed. 1923).

43 Id. at 29. 
abnormally high prices afterwards. The other is when dumping results in the idleness of resources, although the point is generally considered to be incorrect or implausible in subsequent scholarship. ${ }^{44}$

After Viner, there were many economic theories of dumping. ${ }^{45}$ Among them, Willg's dumping theory plays an important part in modern economics. Economists are inclined to conduct empirical studies by applying his criteria of dumping. ${ }^{46}$ The general idea of Willig is to divide dumping into two main categories, i.e., nonmonopolizing dumping (including market-expansion dumping, cyclical dumping and state-trading dumping) and monopolizing dumping (including strategic dumping and predatory dumping). ${ }^{47}$ Adopting an efficiency analysis, he then argues that only monopolizing dumping needs to be regulated. In terms of predatorypricing dumping, where low-priced exporting is geared to driving rivals out of business in order to obtain monopoly power in the importing market, it is beyond doubt that such dumping is harmful to both the importing country and the global economy. ${ }^{48}$ Regarding strategic dumping, economic logic limits its applicability. ${ }^{49}$ An empirical study conducted by Messerlin and others revealed that the only country that practiced strategic dumping was Japan. ${ }^{50}$

Accordingly, under the influence of Viner and Willig, economists generally view dumping as a kind of price discrimination that can be classified into several types according to its motives. Subjecting each type to the efficiency approach, it is generally acknowledged that predatory pricing is the only legitimate economic rationale for prohibiting dumping. ${ }^{51}$

44 "Viner misjudged the true costs of resource mis-allocation in the importing country"; "This argument [that dumping will cause a waste of resources in the importing country as it attempts to adjust to the lower price] will appear again below where dumping below cost makes it somewhat more plausible." See R. DALE, AnTI-DUMPING LAw In a LiberaL Trade Order 3 (1st ed. 1980); supra note 35, at 15; Antidumping Law and Practice: a Comparative Study 28-29 (J. Jackson \& E. Vermulst ed., 1990).

45 Niels, supra note 5, at 473-474.

46 For details, see M. Jallab \& J. Kobak, Antidumping as Anticompetitive Practice Evidence from the United States and the European Union, 6 J. InD. Compet. Trade 253-275 (2006); M. Holden, Anti Dumping: A Reaction to Trade Liberalisation or Anti Competitive?, 70 South African J. Econ. 912-931(2002); A. Aggarwal, Anti Dumping Law and Practice: An Indian Perspective, 85 Working Paper, Indian Council for Research on International Economic Relations (2002), available at http://www.icrier.org/pdf/antiDump.pdf (last visited on Apr. 5, 2013); Araujo, supra note 31 .

47 R.Willig, Economic Effects of Antidumping Policy, in Brookings Trade Forum 61-67 (R. Lawerence ed., 1998).

48 Id. at 73-74.

49 Id. at 64.

50 For details, see Lloyd, supra note 11, at 75; P. Messerlin \& G. Reed, The US and EU Antidumping Policies, 105 THE ECON. J. 1565 (1995).

51 K. Kennedy, Competition Law and the World Trade Organization: The Limits of Multilateralism 235 (2001). See also M. Trebilcock \& R. Howse, The Regulation of International Trade 188 (2nd ed. 1999). 


\section{Dumping in the Evolvement of Antidumping Law: From the Domestic to the International Level}

Since the US adopted its first antidumping policy with the Wilson Act of 1894, many countries have adopted antidumping laws, without much attention to the premises underlying them. ${ }^{52}$ There has been even less knowledge on the justification for antidumping. A more convincing answer requires tracing back antidumping law to its birth and following its evolution. The US Wilson Act of 1894 was the first to introduce antidumping into law. Its birth was closely related to the earliest US federal antitrust law, i.e., the Sherman Act of $1890 .^{53}$ Because the Act had only limited success in preventing the severe export cartels of Germany that were threatening the US after World War I, it was replaced by the US Antidumping Act of 1916 (hereinafter 1916 Act) ${ }^{54}$ Whether this law is an antidumping law or an antitrust law was hotly debated in the WTO 1916 Antidumping Act case. ${ }^{55}$ Although the Panel did not clearly define the nature of the 1916 Act, its reasoning hints that antidumping and antitrust were not separate legal concepts at that time. It regards the former as part of the latter to deal with transnational price discrimination. ${ }^{56}$ In 1921, partly inspired by the Canadian Act of 1904, a new Antidumping Act (hereinafter 1921 Act) was enacted. ${ }^{57}$ The 1921 Act was used as a model for the drafting of the section on dumping in the Havana Charter and GATT. Since its specific rules varied much from those of antitrust law, some scholars deem that the 1921 Act should be considered the 'real' first antidumping law of the US, completely separate from antitrust law. ${ }^{58}$ Observed literally, the 1921 Act actually abandoned many features of the 1916 Act that were typical features of antitrust law. ${ }^{59}$ Nevertheless, if we take into account why the US decided to change these rules, it seems that the changes in the rules have nothing to do with the re-consideration of the policy or philosophy of antidumping law, but were merely designed to avoid the practical difficulties to "halt an expected massive dumping campaign by European cartels designed to destroy a number of fledgling

52 Supra note 8, at 25.

53 Supra note 42 , at 241-242.

54 Id. at 242.

55 See United States-Anti-Dumping Act of 1916 (WT/DS162/R, May 2000), available at http://www.wto.org/english/ tratop_e/dispu_e/1680da.pdf; http://www.wto.org/english/tratop_e/dispu_e/1680db.pdf (last visited on Apr. 5, 2013).

56 Id. at $42-48$.

57 J. Finger, The Origins and Evolution of Antidumping Regulation, in Antidumping: How It Works and Who Gets Hurt 20 (J. Finger ed., 1993).

58 D. Irwin, The Rise of US Antidumping Actions in Historical Perspective, 10582 NBER Working Paper (2004), available at $\mathrm{http}$ //www.nber.org/papers/w10582.pdf?new_window=1(last visited on Apr. 5, 2013).

59 Such as requiring a finding of specific intent to restrain commerce, providing criminal sanctions and private treble damage suits. All of these features were replaced by a duty as a means of curbing dumping. 
American industries and to monopolize American markets. ${ }^{60}$ In short, the changes in US law made antidumping gradually deviate from competition law textually, but the intention was not to assign goals to the law that were different from the original one.

Along with the significant changes in the rules continued afterwards, antidumping gradually moved from the domestic level to the international level, namely, the antidumping agreement regulated under the GATT 1947. In the early twentieth century, while nations dealt with their concerns regarding "unfair trade practices" unilaterally, an effort commenced to deal with dumping through a multinational forum. ${ }^{61}$ In November 1945, the US issued a pamphlet titled, "Proposals for Expansion of World Trade and Employment," including some rules for international trade and an outline for an International Trade Organization ("ITO"). ${ }^{62}$ In the Proposals, the US suggested that one function of ITO would be to formulate "a general definition of circumstances under which antidumping and countervailing duties may properly be applied to products imported from other members. ${ }^{\text {"3 }}$ Largely at the insistence of the US, one of the areas addressed in the original General Agreement was unfair trade in the form of dumping and subsidized exports. ${ }^{64}$ The result of the negotiations in the antidumping duty area was Article VI of GATT. ${ }^{65}$ The rules were further re-defined in the Kennedy Round in 1967 and the Tokyo Round that closed in $1979,{ }^{66}$ and later on specified in a specific international agreement, such as the WTO ADA, which was adopted following the trade negotiations of the Uruguay Round in 1995. Similar to the WTO countervailing agreement, the WTO ADA is categorized as one of the instruments of the trade remedies in the organization. ${ }^{67}$ According to Article 18.4 of the WTO ADA, the Antidumping Agreement is aimed at setting up a standard for antidumping measures to be taken by the WTO members and requires members to implement all possible general or specific measures to ensure that their laws, regulations and administrative procedures conform to it. Therefore, as to the purpose of internationalization, it is not to condemn harmful dumping universally, but to restrain national antidumping actions. ${ }^{68}$ For a long time, the idea that "dumping

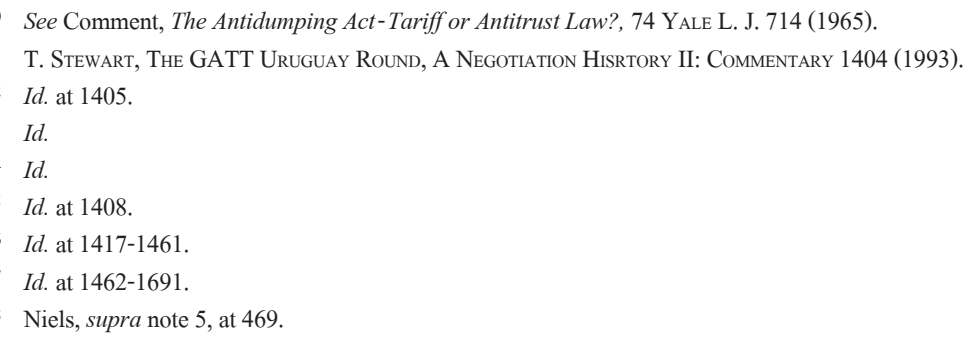


is harmful" was taken as a self-evident premise of antidumping law that required no proof.

To sum up, a journey back to its birth as well as an examination of its evolution indicates that antidumping law is originally part of competition law and aims at curbing import price discrimination. It is for dealing with these foreign conducts more efficiently that antidumping rules were changed and gradually became distinct from competition rules. The idea behind the creation of the international antidumping agreement in WTO was simply to unify domestic rules. Most countries subsequently adopted antidumping laws merely because they had to follow the requirements of WTO. None of the changes were aimed at condemning dumping for reasons other than the original ones, i.e., to avoid predatory dumping.

\section{B. Unfair Trade: Deceptive and Hypocritical Cause}

As mentioned, the US puts forward 'unfair trade' as the 'new goal' of antidumping, which completely cuts off its link to competition law. However, the above comprehensive investigation into the economic theories of dumping as well as the evolution of antidumping law offers no support for such assertion. The core idea of the antidumping system is built on 'predatory dumping. ${ }^{69}$ The system was never designed to deal with such a tremendously broad view of 'fairness,' consisting in both indirectly addressing the harmful results of market-distortive government industrial policies and neutralizing the inequities arising from differences in national economic system. $^{70}$

It is beyond question that these unfair government policies are condemnable or injurious, but the correct way is to address or identify those unfair government policies directly, rather than counting on investigating price differences. ${ }^{71}$ A number of specific examples were provided under each category of "market-distortive government industrial policies" in the communication of the US to WTO, including government policies limiting the number of producers in a particular industry through the restrictive award of licenses, facilitating State monopolies, favoring a 'national champion' firm within an industry, and high tariffs. There are also a number of non-tariff barriers such as import charges, quantitative restrictions,

69 Supra note 42, at 140-141. See also supra note 47, at 65-66.

70 Barfield, supra note 5, at 1-40.

71 H. Bernard, Free Trade and Deep Integration: Antidumping and Antitrust in Regional Agreements, World Bank Development Research Group International Trade (1998), available at http://www-wds.worldbank.org/servlet/ WDSContentServer/WDSP/IB/1998/07/01/000009265_3980928162543/Rendered/PDF/multi0page.pdf (last visited on Apr. 5, 2013). See also supra note 8, at 28. 
import licensing, standards, testing, labeling and certification, sanitary and phytosanitary standards, investment barriers, State trading rights, services barriers, lack of intellectual property protection, government procurement practices, bribery and corruption. ${ }^{72}$ With such a broad notion of unfair trade, almost every government industrial policy can be the cause of an antidumping action. ${ }^{73}$

The problem is that those unfair government policies have no direct relation at all with the conduct of low-price selling. Even if they are injurious and condemnable, would it not be more efficient and rational to address or identify them case by case, and target them directly after proving that they exist? Barfield illustrated each listed policy. ${ }^{74}$ For instance, the tariff rates have been set as a result of negotiations by individual nations in the Uruguay Trade Round. If a WTO member breaks the agreement and raises its rates, it must renegotiate them with all other WTO members or face retaliation. ${ }^{75}$ As to industrial subsidies, WTO has set rules for illegal and legal subsidies. If these rules are violated, a case can be brought before WTO. ${ }^{76}$ Similar comments can be given for the other listed policies. ${ }^{77}$ Actually, all the policies in the list can and should be addressed in a direct way.

Even if an indirect mechanism for maintaining fair and free multilateral trade is necessary, antidumping is far from qualified to fulfill this function. The proliferation of antidumping cases suggests that the following have led to protectionist abuse: (1) the indirect way to address the broad and blurry concept of 'unfair trade' via antidumping; (2) the investigation focusing on price differences rather than targeting the unfair government policies themselves; and (3) the remedy taking the form of removing price differences rather than correcting or condemning the unfair government policies themselves.

Consequently, the arguments based on the prevention of 'unfair trade' are deceptive and hypocritical. The antidumping system cannot act as a good protector against such a broad notion of 'unfair trade.' In fact, some scholars have criticized national legislators for antidumping laws and the architects of GATT/WTO for their understanding that the action was essentially protectionist. ${ }^{78}$ However, they

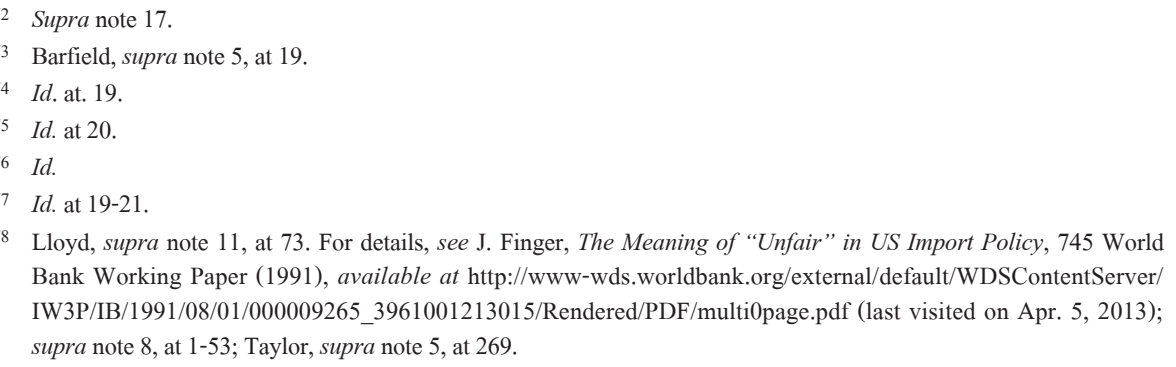


described it as designed to combat 'unfair' trade in order to disguise such intent. ${ }^{79}$

\section{Quasi Safeguard: Do We Need Two Protective Mechanisms?}

Apart from the concern with 'unfair trade,' another more persuasive justification of antidumping law is the so-called 'quasi safeguard' measure. Under this view, the antidumping system is supposed to protect domestic competitors by neutralizing the inequities arising from differences in national economic system. ${ }^{80}$ However, the above examination suggests that antidumping is not designed to be a mechanism for a protective purpose. In the modern multilateral free trade system, it is understandable that countries need a protective mechanism against injury to domestic competitors. However, such mechanism has no direct relationship with the conduct of low-price selling.

Considering that safeguard measures, which clearly regard 'protection' as their essential purpose, are already available under the current framework, why do we need another mechanism that aims at exactly the same protective purpose? The better instrument for providing temporary protection to inefficient industries is a safeguard measure, instead of antidumping. ${ }^{81}$ As a protective mechanism, safeguard measures have many advantages over antidumping. For instance, in determining a safeguard action, the relevant authorities can take into account the overall national welfare and other political and diplomatic factors which cannot be achieved by antidumping. ${ }^{82}$ Increasing use of safeguard actions would reduce the inflammatory and often-spurious comparisons made between 'fair' and 'unfair' trade practices. Indeed, as Jackson states, the distinction between fair and unfair trade has become more blurred..$^{83}$ Antidumping measures often target a country, whereas safeguard measures must be imposed without national discrimination and with compensation. As a protective measure, the unselective and reciprocal safeguard is more consistent with the basic trade principle of non-discrimination.

Even if two or more different protective mechanisms could be kept as the 'pressure valve' to maintain an open trade policy, antidumping has fundamental weaknesses. If the modern world views the removal of all trade barriers as

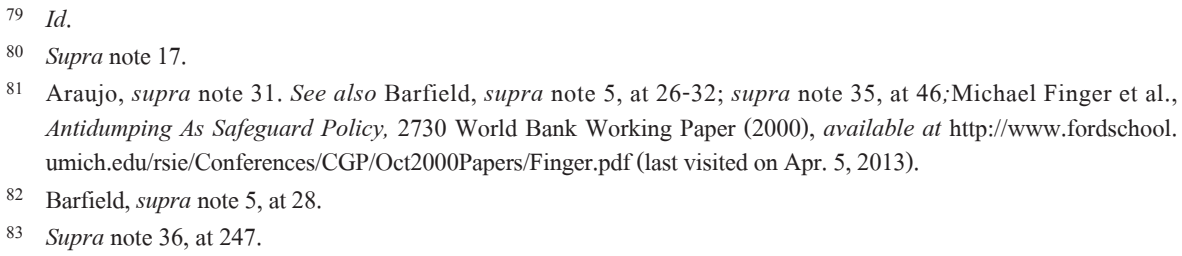


essential, and hence strictly limits domestic protection, why does it allow such a loose protective measure as antidumping to be used on such a large scale? The only possible reason why governments prefer antidumping on such a large scale is not because it is a better protective policy, but because it is easier to apply. ${ }^{84}$ Finger deemed that there are two basic criteria to value an appropriate protective mechanism in the modern free trade world. One is whether it can help the government to separate trade interventions that would serve the national economic interests from those that would not; and the other is even in those instances in which the decision is to restrict imports, whether it can support the politics of openness and liberalization. ${ }^{85}$ Antidumping fails to satisfy either criterion. It only focuses on the economic impact on the domestic economy, and gives more weight to competitive domestic interests than domestic users. Moreover, it fails to support openness or liberalization because it treats foreign competitors discriminatively and biasedly. The proliferation of antidumping cases has reinforced that it is not a controllable protective mechanism in the free trade system. On the contrary, antidumping has been largely abused for protectionist purposes and it is actually against the basic spirit of modern free trade.

\section{Summary}

"Why dumping is harmful" remains a controversial and unclear issue. By examining various economic theories on dumping, tracing antidumping law's origins, and following the evolution from domestic antidumping law to the international antidumping agreement, it is considered that the only rationale of antidumping law is to deal with international predatory dumping, more specifically its rules on predatory pricing, which is also regulated under competition law. The arguments based on the need to prevent 'unfair trade' are deceptive and hypocritical. The antidumping system is not aimed at and cannot qualify as a protective mechanism that is controllable and necessary for the global free trade system.

84 Araujo, supra note 31.

85 Finger, supra note 81. 


\section{Competition and Antidumping: What is Next on the Agenda?}

\section{A. Predatory Pricing Rules versus Antidumping Rules}

Given that both antidumping law and competition law target the same anticompetitive practice, i.e., predatory dumping / pricing, the question arises whether dumping would not be more appropriately regulated by competition law. Specifically, we need to ascertain whether regulating dumping through competition law would lead to less protectionist abuse.

Though no international predatory pricing rules yet, scholars have pointed out that, unlike other areas of competition law, some consensus has been reached with respect to price predation. ${ }^{86}$ Four common requirements for predatory pricing can be identified in the US, the EU, and most of the other major trading countries, including (1) a high threshold of or dominant market power, (2) requisite intent, (3) price-below-cost calculation, and (4) injury to competition. ${ }^{87}$ Competition authorities in different countries may choose to emphasize one particular element in different time periods. In the US, e.g., the relevant federal provisions on predatory pricing are found in the following three statutes: the Sherman Act (general approach), ${ }^{88}$ the Clayton Act (a more specific approach), ${ }^{89}$ and the Robinson-Patman Act (an amendment)..$^{90}$ Previously, the US antitrust law focused on cost calculation. However, it has since shifted to a strict recoupment analysis that emphasizes the harm to competition. In the EU, predatory pricing is prohibited by Article 102 of the Treaty on the Functioning of the European Union (ex-Article 82 of EC Treaty). ${ }^{91}$ As a relatively new issue, much attention is paid to cost calculation.

Niels, supra note 5, at 485. See also G. Niels \& A. Kate, Predatory Pricing Standards: Is There A Growing International Consensus? 45 Antitrust Bull. 807 (2000); Kennedy, supra note 51, at 231.

87 Supra note 35 , at 262.

8815 USC. $\$ 11-7$.

89 Id. $\S 12-27$.

$90 \quad I d . \S 13$.

91 It reads: "Any abuse by one or more undertakings of a dominant position within the common market or in a substantial part of it shall be prohibited as incompatible with the common market insofar as it may affect trade between Member States. Such abuse may, in particular, consist in: (a) directly or indirectly imposing unfair purchase or selling prices or other unfair trading conditions; (b) limiting production, markets or technical development to the prejudice of consumers; (c) applying dissimilar conditions to equivalent transactions with other trading parties, thereby placing them at a competitive disadvantage; (d) making the conclusion of contracts subject to acceptance by the other parties of supplementary obligations which, by their nature or according to commercial usage, have no connection with the subject of such contracts." 
A careful comparison of the two sets of rules leads to the impression that predatory pricing rules are more meticulous than antidumping rules in dealing with low-price selling and less prone to abuse for protectionism in various aspects. With regard to the objectives, modern competition policy governing predatory pricing rules is concerned with protecting the competitive process rather than individual competitors. It aims at promoting economic efficiency as well as consumer welfare, and takes the overall welfare of the country into consideration, rather than only protecting the welfare of producers. ${ }^{92}$ Hence, predatory pricing rules are less likely to be abused by those domestic firms with vested interests, and thereby are less susceptible to protectionism.

On the substance, predatory pricing rules are more selective in their application and more effective at distinguishing between fair and unfair trade practices. Since low-price selling may have either a pro-competitive or an anti-competitive effect, competition rules are much more careful and sophisticated in distinguishing between healthy competition and harmful predatory conducts, without being abused for protectionism. ${ }^{93}$

From the perspective of basic procedural regulations, antidumping rules allow for broad discretion and therefore offer numerous possibilities for an efficient protection of domestic vested interests. ${ }^{94}$ By contrast, with comparatively clearer objectives and stricter methodological guidelines, competition law enforcers have significantly less discretion than the enforcement authorities of antidumping rules in implementing their respective laws. ${ }^{95}$ Moreover, as a rather judicial-based procedure, the whole competition investigation is comparatively fair and equal, giving foreign competitors better due process guarantees. ${ }^{96}$

Lastly, with respect to remedies, the imposition of antidumping duties, price undertaking, etc. under antidumping law does not bear directly on the firms or firms' competitive behavior. The remedies can only raise the price of the dumped good for the duration of the action to compensate the victims, but cannot prohibit the unfair behavior from reoccurring. ${ }^{97}$ The remedies under competition law, which

92 Kennedy, supra note 51, at 235. See also M. Mendes, Antitrust in A World of Interrelated Economies: the Interplay between Antitrust and Trade Policies in the US and the EEC 149 (1st ed. 1991); Taylor, supra note 5, at 264.

93 For details, see Ying Bi, Substituting Antidumping Law with Competition Law: the Better Option in Avoiding Protectionist Abuse, 76 Hoser KenKyu 481-492 (2009).

94 Id. at $478-481$.

95 Id. at $478-479$.

96 Id. at 478. For details, see Kennedy, supra note 51, at 235.

97 Supra note 94, at 476-478. 
can directly target and penalize the anti-competitive practice, are more appropriate. ${ }^{98}$

The author would advocate that antidumping law should be substituted by competition law. Unfortunately, the political reality is that antidumping is not likely to be abolished soon around the world. As Wooton and Zanardi suggest, supranational application of competition policies may be the 'best' solution on efficiency grounds. It is not considered politically feasible, however. ${ }^{99}$ Indeed, the subject of antidumping is so politically sensitive in the US that its trade negotiators are reluctant to put it on the WTO agenda. ${ }^{100}$ In the multilateral field, the WTO practice showed that it was really hard to progress on negotiating stricter rules on antidumping measures. Although the ADA agreed in the Uruguay Round constituted an improvement over the prior GATT requirements, they did little to compensate for the fact that antidumping authorities retain substantial discretion in applying regulations and defining criteria. ${ }^{101}$ Seven years later when antidumping was once again brought up on the reform agenda in the Doha Round, the negotiating mandate for antidumping from the beginning closed the door for any substantial changes since it was agreed that the "basic concepts, principles and effectiveness" of antidumping must be preserved. ${ }^{102}$ Such pessimistic prediction has been further demonstrated in the following discussion on the Draft Consolidated Chair Texts of the AD and SCM Agreements of 2007. ${ }^{103}$ None of the essential issues including zeroing, public interest and sunset review were agreed thereto. The 'profoundly divided' or 'sharply divided' opinions on them were explained in the New Draft Consolidated Chair Texts of the AD and SCM Agreements of 2008. ${ }^{104}$ Still, antidumping reform is not visible in WTO. Therefore, the idea of gradually incorporating predatory pricing rules into antidumping investigations in bilateral and regional trade zones seems more feasible and realistic.

98 Id. at 476. See also Lloyd, supra note 11, at 76.

99 See Wooton \& Zanardi, supra note 5, at 13.

100 R. Litan, Moving Towards an Open World Economy: The Next Phase (Brookings, 1999), available at http://www. brookings.edu/papers/1999/1206globaleconomics_litan.aspx (last visited on Apr. 5, 2013).

101 Supra note 4.

102 See The Doha Mandate, available at http://www.wto.org/english/thewto_e/minist_e/min05_e/brief_e/brief08_e.htm (last visited on Apr. 5, 2013)

103 See Draft Consolidated Chair Texts of the AD and SCM Agreements (TN/RL/W/213, Nov. 2007), available at https://docs.wto.org/dol2fe/Pages/FE_Search/FE_S_S009-1.aspx?language=E\&CatalogueIdList=71755,82383,737 $56,61095,70293,66793,74524,73940,76234,100587 \&$ CurrentCatalogueIdIndex $=4 \&$ FullTextSearch $=$ (last visited on Apr. 5, 2013).

104 See New Draft Consolidated Chair Texts of the AD and SCM Agreements (TN/RL/W/236, Dec. 2008), available at https://docs.wto.org/dol2fe/Pages/FE_Search/FE_S_S009-1.aspx?language=E\&CatalogueIdList=69053,83670,861 $11,93491,82551,91426,91367,91251,85265,83642 \&$ CurrentCatalogueIdIndex $=0 \&$ FullTextSearch $=($ last visited on Apr. 5, 2013). 


\section{B. From RTAs to WTO: A Step-by-Step Reform}

There have already been successful practices of substitution in a small number of regional trade agreements ("RTAs"). For instance, the EU, the European Free Trade Association ("EFTA"), and the European Economic Area ("EEA") have all decided to abandon antidumping investigations among regional members and adopted a unified regional competition law. Australia-New Zealand Closer Economic Relations Trade Agreement ("ANZCERTA") has also completed the plan to harmonize domestic competition law to eliminate antidumping law. ${ }^{105}$ Similar practices of replacement have been achieved in both the EFTA-Singapore FTA (2003) and the EFTA-Chile FTA (2004). ${ }^{106}$ Some RTAs, such as the MERCOSUR ${ }^{107}$ and the Latin American and Caribbean System ("SELA") ${ }^{108}$ have been conducting various reforms and intend to harmonize rules in the future.

Efforts devoted to the aim of dealing with dumping through a harmonized competition law should be expanded to more RTAs, especially among the countries or areas that have a 'like-mindedness' on the issue of antidumping. In those RTAs relating to the Friends of Antidumping Negotiations ("FANs") including China, Japan, Korea, Singapore, Chile and EFTA, an array of intra-regional modifications has been endeavored to make both the substantive and the procedural aspects of the WTO ADA more stringent. ${ }^{109}$ During such efforts, a scheme of gradually incorporating predatory pricing rules into antidumping rules should also be taken into consideration. Introducing a similar 'market share' test as applied in predatory pricing rules into antidumping investigations, or giving more weight to consumers in the recognition

105 Taylor, supra note 5, at 273-276. See also Bernard, supra note 71, at 3-4.

106 For details, see T. Voon, Eliminating Trade Remedies from the WTO: Lessons from Regional Trade Agreements, 59 InT'L \& Comp. L.Q. 625-667 (2010); E. Emerson, Trade Remedy Provisions in Regional Trade Agreements, Asia Pacific F. News (2008), available at http://www.steptoe.com/assets/attachments/3465.pdf (last visited on Apr. 5, 2013); R. Teh et al., Trade Remedy Provisions in Regional Trade Agreements, WTO Staff Working Paper (2007), available at http://papers.ssrn.com/sol3/papers.cfm?abstract_id=1019414; http://papers.ssrn.com/sol3/papers. cfm?abstract_id=1019414 (all last visited on Apr. 5, 2013).

107 Supra note 6.

108 See The First Working Group on Trade and Competition for Latin American and Caribbean Countries, available at http:/www.unctad.org/Templates/Page.asp?intItemID=6014\&lang=1 (last visited on Apr. 5, 2013).

109 The WTO ADA substantive rules-plus modification include: Increasing the threshold for determining 'negligible' imports from two per cent to five per cent; Increasing the standards for de minimis dumping margins in investigations from two per cent to five per cent; Eliminating the practice of 'zeroing' in calculating dumping margins; Use of the 'lesser duty' rule; An agreement to eliminate the application of any third country dumping provisions as otherwise permitted by Article 14 of the AD Agreement; Recognition of the 'public interest' in making AD determinations. The WTO ADA procedural rules-plus modification includes: the referral of any antidumping dispute to a 'joint committee'; A pre-initiation consultation between the governments before initiating an antidumping proceeding. See Emerson, supra note 106. 
of 'public interest' during antidumping determinations might be taken as an initial step. ${ }^{110}$ With all of the above practices broadened in RTAs, as well as the effects of 'role reversibility' gained from the rapidly increased use of antidumping laws by developing countries against the US and the $\mathrm{EU}^{111}$ it might then be possible to bring the issue of antidumping on the agenda of multilateral negotiations again. ${ }^{112}$

\section{Conclusion}

The debate of antidumping versus competition is a relatively new, but very significant issue. With the proliferation of antidumping laws and actions around the world, especially after the developing countries joined the camp, the antidumping rules' increasing potential for protectionist abuse has been criticized in almost all of the current literature. Many proposals have been brought up with the same purpose to reform the antidumping system. Recently, an increasing number of scholars started to rethink the fundamental basis for the existence of the whole antidumping system. They are arguing that further fine-tuning and refining of antidumping policy is not the answer to prevent its misuse. Rather, the antidote is competition policy. Although due to other political factors, the subject of trade and competition was decided to be put aside within the WTO during Doha Round in 2004, the economic crisis in 2009 has once again raised calls for greater coherence between trade and competition policies. Some, especially those from the developing countries, once again require introducing competition into trade, so as to explore on a new development model of "how the interaction of competition and trade policy can contribute to economic development." ${ }^{113}$

In line with other literature, the author has attempted to contribute to the debate of integrating antidumping with competition from the angle of reexamining the fundamental justification of antidumping law. Although the WTO ADA is quite

110 P. Messerlin, Should Antidumping Rules be Replaced by National or International Competition Rules, 49 THE SwISS Rev. Int'L Econ. Relations 351-371 (1994). See also Lloyd, supra note 11, at 66-81; Y. Akbar, Global Antitrust: Trade and Competition Linkages 159 (1st ed. 2003); R. Grey, The Relationship Between Anti-dumping Policy and Competition (UNCTAD, 1999), available at $\mathrm{http} / /$ www.iatp.org/files/Relationship_between_Anti-Dumping_Policy_ and_C.htm (last visited on Apr. 5, 2013); Aggarwal, supra note 46.

111 M. Wu, Antidumping in Asia's Emerging Giants, 53 Harv. INT'L L.J. 1-73 (2012).

112 See Anti-dumping Initiations: By Reporting Member 01/01/1995 - 30/06/2012, available at http://www.wto.org/ english/tratop_e/adp_e/AD_InitiationsByRepMem.pdf (last visited on Apr. 5 , 2013).

113 See The WTO Forum, available at http://www.wto.org/english/forums_e/debates_e/debate19_e.htm (last visited on Apr. 5, 2013). 
specific in rules, it remains silent on the justification of antidumping law. For a long time, "dumping is harmful" seems a self-evident premise so as to warrant multilateral free trade. An overall survey of the WGTCP documents identifies the following three main different viewpoints on the justification of antidumping law: (1) Eliminate 'predatory dumping' intended to monopolization; (2) Protect against 'unfair trade' resulted from various market-distortive government industrial policies; and (3) Function as a 'quasi safeguard' measure to ameliorate the effects of different economic structures.

The author confirms that the only legitimate rationale of antidumping law is to deal with international predatory dumping pricing. The alleged arguments for broadly combating 'unfair trade' are deceptive and hypocritical, because the antidumping system is not to protect the global free trade world.

Modern competition rules are more meticulous than antidumping rules in dealing with low-price selling and are less prone to being abused for protectionism in various aspects. Considering the difficulty in distinguishing between 'predatory behavior' and 'fierce competition,' the courts are usually reluctant to conclude the occurrence of predatory pricing. ${ }^{114}$ Hence, successful predatory pricing actions are extremely rare in competition law, whereas no such difficulties arise in antidumping actions. ${ }^{115}$ A series of empirical studies on "what would happen if competition standards were applied to antidumping cases" also confirm that only very few antidumping cases are candidates for closer examination on predation grounds. ${ }^{116}$ In that sense, competition regime would better help suppress the protectionism intent of many governments than antidumping.

Antidumping law should be substituted by competition law. However, antidumping is not likely to be abolished soon. This paper would thus conclude with a proposal to gradually achieve substitution by moving from bilateral or regional trade areas to WTO. As the first step, incorporating a 'market share' test into antidumping investigations, or giving more weight to 'consumer interest' in the framework of antidumping determinations, should be seriously considered, particularly in those RTAs relating to the FANs, such as the China-Korea FTA and the China-Japan-Korea FTA. Still, a more detailed proposal towards a step-by-step reform needs further research. Although a relatively modest change, it could be the stepping stone in a series that would eventually lead to the disappearance of antidumping law.

114 Taylor, supra note 5, at 278.

115 Id.

116 Ying Bi, The Application of a 'Market Share' Test to Antidumping Cases in China: Seeking a New Development Model via the Interaction of Trade and Competition, 8 MANCHESTER J. INT'L ECON. L. 36-56 (2011). 
